\title{
Cavernous sinus syndrome in dogs and cats: case series (2002-2015)
}

\author{
Aslynn M. Jones ${ }^{1,2}$, Ellison Bentley ${ }^{3}$ and Helena Rylander ${ }^{1, *}$ \\ ${ }^{I}$ Department of Medical Sciences, School of Veterinary Medicine, University of Wisconsin, Madison, WI 53706, \\ USA \\ ${ }^{2}$ Current Address: Colorado State University, Fort Collins, CO 80523, USA \\ ${ }^{3}$ Department of Surgical Sciences, School of Veterinary Medicine, University of Wisconsin, Madison, WI 53706, \\ USA
}

\begin{abstract}
The cavernous sinus (CS) is a paired venous sinus that runs along either side of the pituitary gland on the floor of the calvarium. Cavernous sinus syndrome (CSS) refers to deficits in more than one of the cranial nerves III, IV, V, and VI, as they are in close association in this region. The purpose of this study was to identify the presenting complaints, neurologic findings, diagnosis, and outcomes in dogs and cats with confirmed cavernous sinus syndrome (CSS). Medical records between 2002 and 2015 were reviewed. Inclusion criteria were neurologic signs consistent with CSS and advanced imaging and/or post-mortem examination. Thirteen dogs and 2 cats were included. Twelve dogs received advanced imaging. Post-mortem examination was performed on 2 cats and 3 dogs. Dogs were $6-13$ years (mean $=10.8$ years) of age and comprised of several different breeds. Both cats were male neutered domestic shorthair, ages 3 and 14 years. Presenting complaints included mydriasis $(\mathrm{N}=4)$, behavior changes $(\mathrm{N}=3)$, hyporexia $(\mathrm{N}=3)$, ptosis $(\mathrm{N}=2)$, ataxia $(\mathrm{N}=2)$, pain $(\mathrm{N}=2)$, weakness $(\mathrm{N}=2)$, lethargy $(\mathrm{N}=2)$, and one each of epiphora, ocular swelling, polydipsia, seizures, facial muscle atrophy, dysphagia, and head tilt. Neurologic signs included ophthalmoparesis/plegia $(\mathrm{N}=13)$, reduced/absent pupillary light response $(\mathrm{N}=11)$, mydriasis $(\mathrm{N}=10)$, reduced/absent corneal sensation $(\mathrm{N}=7)$, ptosis $(\mathrm{N}=6)$, reduced facial sensation $(\mathrm{N}=2)$, and enophthalmos $(\mathrm{N}=1)$. Thirteen patients had a mass lesion within the cavernous sinus, 6 of which were confirmed neoplastic via histopathology. Median survival time for the 4 patients treated with radiation therapy was 1035 days (range 150-2280). Median survival for the 4 patients that received medical treatment was 360 days (range 7-1260 days), and for the 5 non-treated patients 14 days (range 0-90 days). In conclusion mydriasis and ophthalmoplegia are common signs of CSS. A mass lesion within the CS is the most common cause. Survival time may be improved with radiation therapy.

Keywords: Anisocoria, Cavernous sinus, Mydriasis, Ophthalmoplegia.
\end{abstract}

\section{Introduction}

The cavernous sinus (CS) is a paired venous sinus that runs along either side of the pituitary gland on the floor of the calvarium. The CS extends from the orbital fissure to the petro-occipital canal and is responsible for the venous drainage from the frontal sinus and nose. Cranial nerves III (CN III, oculomotor nerve), IV (CN IV; trochlear nerve), VI (CN VI; abducent nerve), and the maxillary and ophthalmic branches of $\mathrm{V}(\mathrm{CN} \mathrm{V}$; trigeminal nerve) are in close association with the CS (Evans and de Lahunta, 1988; Penderis, 2004). To correctly identify deficits in these nerves it is imperative to understand their function. CN III supplies motor innervation to extraocular muscles (dorsal, medial, and ventral rectus) and the ventral oblique muscle of the eyeball. The levator palpebra muscle of the upper eyelid is also innervated by CN III. The parasympathetic portion of CN III supplies the iris and ciliary muscles. CN IV only innervates the dorsal oblique muscle and for this reason deficits can be challenging to detect. CN VI innervates the lateral rectus and retractor bulbi muscles. CN V (maxillary, mandibular, ophthalmic) supplies sensory afferent information to the entire face, additionally the mandibular branch provides motor to the muscles of mastication. Cavernous sinus syndrome (CSS) refers to deficits in more than one of the cranial nerves III, IV, V (maxillary, ophthalmic), and VI (Penderis, 2004). The sympathetic innervation to the eye also travels through the region of the CS; for this reason, Horner's syndrome may accompany other clinical signs consistent with cavernous sinus syndrome (Dewey, 2008).

Common clinical signs associated with a lesion within the cavernous sinus in dogs and cats include external ophthalmoparesis or ophthalmoplegia (CN III, IV, VI), ptosis (CN III), reduced or absent direct and indirect pupillary light response (PLR) (CN III), mydriasis (CN III), reduced to absent corneal sensation ( $\mathrm{CN} \mathrm{V}$ ophthalmic), in addition to decreased facial sensation 
(CN V) (Theisen et al., 1996; Rossmeisl et al., 2005). Signs may be unilateral or bilateral, depending upon the size and location of the lesion(s).

Previous retrospective studies in dogs and cats have found anisocoria, mydriasis, and abnormal ocular motility to be the most common presenting complaints. Neoplasia and infectious diseases have been reported as the most common underlying etiologies of CSS. (Theisen et al., 1996; Rossmeisl et al., 2005). Lymphoma, thyroid adenocarcinoma, neuroendocrine carcinoma, chemodectoma, meningioma, chondrosarcoma, and primitive neuroectodermal tumors are histologically confirmed tumors found in this region previously. Other reported causes in dogs and cats include: infectious and non-infectious inflammatory diseases, multiple cartilaginous exostosis, trauma, and vascular lesions such as cavernous sinus fistulas (Theisen et al., 1996; Tidwell et al., 1997; Rossmeisl et al., 2005; Hernandez-Guerra et al., 2007; Perazzi et al., 2013; Guevar et al., 2014). Infectious etiologies have been reported more commonly in cats when compared to dogs and include: feline infectious peritonitis, cryptococcus neoformans, and toxoplasma gondii (Theisen et al., 1996). A recent case report of CSS in a Holstein bull identified abscessation extending through the round foramen and obliterating the cavernous sinus region. This bull presented for unilateral exophthalmos (Jacob et al., 2015).

In humans, diplopia and periocular pain have been reported as the most common presenting symptoms. Neoplasia appears to be the most common underlying etiology for CSS in humans with pituitary adenoma and meningioma most frequent reported in one case series of 126 patients (Fernandez et al., 2007). Bilateral and unilateral metastasis has also occurred with breast carcinoma, lymphoma, lung cancer, prostate cancer, and gastric adenocarcinoma (Ebert et al., 2009). Vascular events and non-specific inflammation of the cavernous sinus or Tolosa-Hunt syndrome have also been reported (Fernandez et al., 2007).

There are limited case reports in the literature of cavernous sinus syndrome in dogs, cats, and cattle. The purpose of this case series is to identify the common presenting complaints, clinical presentations, diagnosis, and outcomes in dogs and cats with cavernous sinus syndrome.

\section{Materials and Methods}

Medical records were reviewed from the University of Wisconsin Veterinary Medical Teaching Hospital between 2002 and 2015. Records were selected if cavernous sinus syndrome was suspected based on examination. Dogs and cats were included in the study if a board-certified neurologist or ophthalmologist confirmed neurologic deficits consistent with CSS (deficits in more than one of the cranial nerves III, IV,
V (maxillary, ophthalmic), and VI). Additionally, advanced imaging (computed tomography or magnetic resonance imaging) or post-mortem examination was required for inclusion in the study. Patients were excluded if they were discharged or euthanized without advanced imaging or post-mortem histopathology. The following ancillary diagnostics were performed on one or more of the study patients: complete blood count, chemistry profile, urinalysis, thoracic radiographs, abdominal ultrasound, CSF analysis, infectious disease testing (Neospora caninum, Cryptococcus neoformans, Blastomyces spp., Toxoplasma gondii, Felv, FIV, FIP), and brain biopsy.

\section{Results}

Fifteen dogs and 8 cats with clinical signs consistent with cavernous sinus syndrome were identified. Two dogs and 6 cats were excluded due to lack of advanced imaging or post-mortem evaluation. Therefore $13 \mathrm{dogs}$ and 2 cats were included in this study. Magnetic resonance imaging was performed on $11 \mathrm{dogs}$, while computed tomography was utilized in $1 \mathrm{dog}$.

Eight dogs were spayed females and 5 were neutered males. The age of the dogs was between 6 and 13 years (mean $=10.8$ years). Breeds included the following: Dalmatian, Jack Russell Terrier, Shetland Sheepdog $(\mathrm{N}=2)$, Shih Tzu, Greyhound, Wheaton Terrier, Beagle, Weimaraner, Rottweiler cross, Samoyed, West Highland White Terrier, and Italian Greyhound. Both cats were neutered male Domestic Shorthair breeds, aged 3 years and 14 years.

Seven of the patients presented to the Ophthalmology service, 7 to the Neurology service, and 1 patient to the Oncology service. The Emergency service initially evaluated 2 of these patients; one was transferred to the Ophthalmology service and the other to the Neurology service.

Presenting complaints made by owners of dogs included: epiphora $(\mathrm{N}=1)$, mydriasis $(\mathrm{N}=3)$, ptosis $(\mathrm{N}=2)$, behavior changes $(\mathrm{N}=3)$, ataxia $(\mathrm{N}=2)$, hyporexia $(\mathrm{N}=3)$, non-localized or cervical pain $(\mathrm{N}=2)$, weakness $(\mathrm{N}=2)$, and lethargy $(\mathrm{N}=2)$. Remaining presenting complaints that occurred in 1 dog each included: polydipsia, recent onset seizure activity, facial muscle atrophy, dysphagia, and a left sided head tilt. Some canine patients presented with more than one owner complaint. Presenting complaints made by cat owners were as follows: left sided ocular swelling and discharge $(\mathrm{N}=1)$ and unilateral left sided mydriasis $(\mathrm{N}=1)$.

All patients had neurologic deficits consistent with cavernous sinus syndrome as identified by one or more of the following: external ophthalmoparesis or ophthalmoplegia $(\mathrm{N}=13)$, reduced or absent direct and indirect pupillary light response $(\mathrm{N}=11)$, mydriasis $(\mathrm{N}=10)$, reduced to absent corneal sensation $(\mathrm{N}=7)$, ptosis $(\mathrm{N}=6)$, and reduced facial sensation $(\mathrm{N}=2)$. 
Other less frequent clinical signs identified included: facial nerve paralysis or paresis $(\mathrm{N}=4)$, paw replacement deficits $(\mathrm{N}=4)$, exophthalmos $(\mathrm{N}=1)$, spontaneous vertical nystagmus $(\mathrm{N}=1)$, ventral strabismus $(\mathrm{N}=1)$, head tilt $(\mathrm{N}=3)$, temporalis and masticatory muscle atrophy $(\mathrm{N}=1)$, enophthalmos $(\mathrm{N}=1)$, cervical pain $(\mathrm{N}=1)$, and obtunded mentation $(\mathrm{N}=1)$.

All but one patient had unilateral CSS signs. Of these patients with unilateral signs, 9 had left-sided clinical signs and 6 had right-sided clinical signs. The one patient with bilateral CSS also had concurrent bilateral facial nerve paralysis of unknown etiology. Magnetic resonance imaging revealed a normal cavernous sinus and mild meningeal enhancement. Additional diagnostics were not performed, precluding a definitive diagnosis in this dog. This was the only patient in the current study that presented with bilateral clinical signs. A lesion within the cavernous sinus was confirmed via magnetic resonance imaging (MRI) in 10/11 dogs. Of those dogs, 9 had a mass lesion within the cavernous sinus. Illustrations of mass lesion within the cavernous sinus are seen in Figures 1 and 2.

One dog had imaging findings consistent with multifocal central nervous system disease. Additional infectious disease testing was performed on this patient. Neospora caninum IFA titer results were 1:100 and a Toxoplasma gondii IgM titer was 1:256 and IgG was negative. Euthanasia was elected shortly after initial diagnosis and post-mortem examination and additional testing was not performed but would have been necessary to identify an underlying etiology for these multifocal clinical signs. Computed tomography (CT) was utilized to confirm a mass lesion invading the cranial vault in 1 patient. Detailed description of neurologic deficits, imaging findings, and outcomes for all patients are seen in Table 1 .

Analysis of cerebrospinal fluid collected from the cerebellomedullary cistern was performed in 11 dogs and 1 cat. A mixed pleocytosis was identified in 4 patients, mononuclear pleocytosis in 1 patient, and albuminocytologic dissociation in 2 patients ( 1 cat and $1 \mathrm{dog})$. Cerebrospinal fluid analysis was within the normal reference range in the remaining 5 patients.

Post-mortem examination was performed on a total of 5 patients ( 2 cats, 3 dogs) and confirmed the presence of neoplasia within the cavernous sinus in all 5 patients. Two of these patients had magnetic resonance imaging performed prior to euthanasia. Ante-mortem histopathology confirmed neoplasia in $1 \mathrm{dog}$ that had a CT scan performed. Histopathologic examination of these 6 patients revealed the following: meningioma $(\mathrm{N}=2)$, adenosquamous carcinoma $(\mathrm{N}=1$, cat), pituitary chromophobe adenocarcinoma $(\mathrm{N}=1)$, high grade malignant lymphoma ( $\mathrm{N}=1$, cat), and amelanotic melanoma $(\mathrm{N}=1)$.

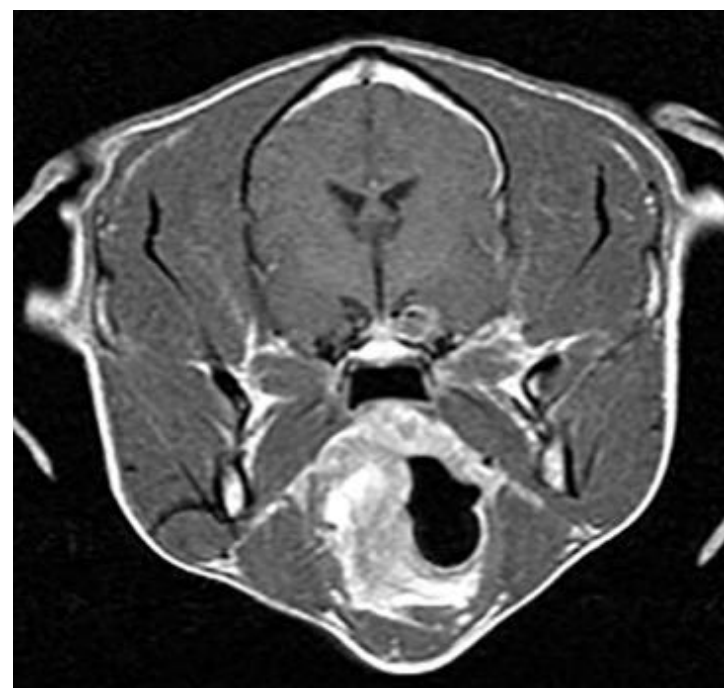

Fig. 1. T1 weighted post contrast transverse image at the level of the cavernous sinus in a dog. Note the contrast enhancing lesion in the left cavernous sinus.

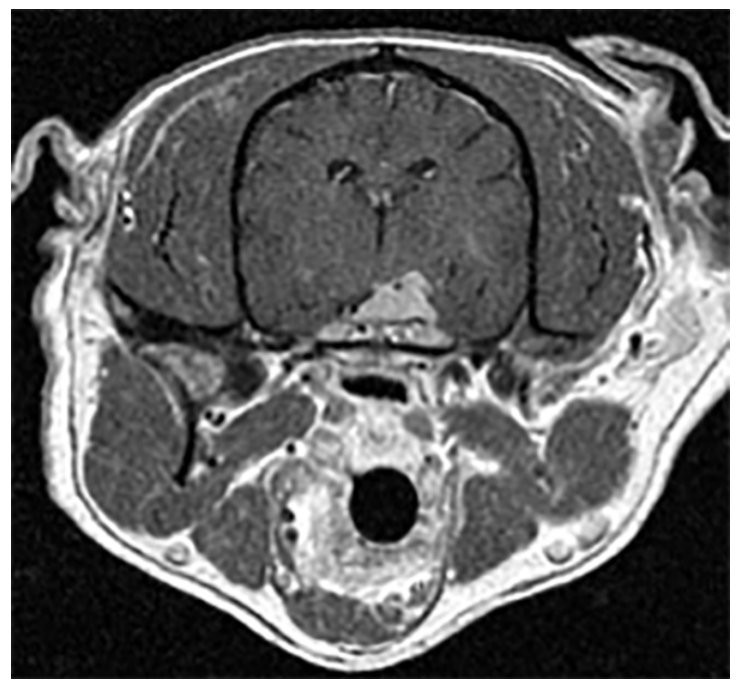

Fig. 2. T1 weighted post contrast transverse image at the level of the cavernous sinus in a dog. There is a contrast enhancing mass involving the left cavernous sinus.

Follow up was available for $13 / 15$ patients. Four dogs received radiation therapy following diagnosis of a mass lesion within the CS. The median survival time for these dogs was 1,035 days (range 150-2280 days). One of these dogs received three fractions of stereotactic radiation therapy and was still alive at the time of this study, 1410 days after initial diagnosis. This patient has a persistent mydriasis of the left eye with no other reported neurologic deficits. Four dogs were treated with anti-inflammatory doses of steroids. Median survival time for these 4 patients was 360 days (range 7-1260 days). The median survival time for 5 patients ( 3 dogs and 2 cats) that did not receive treatment was 14 days (range 0-90 days), with 2 dogs being euthanized at time of diagnosis. 
Table 1. Clinical signs, diagnostic results, and outcome in dogs and cats.

\begin{tabular}{|c|c|c|c|c|c|c|}
\hline Patient & Neurologic deficits & Advanced imaging & $\begin{array}{l}\text { Ancillary } \\
\text { diagnostics }\end{array}$ & $\begin{array}{l}\text { Post-mortem/ } \\
\text { histopathology }\end{array}$ & Treatment & Outcome \\
\hline 1 & $\begin{array}{l}\text { OS: Absent PLR, fixed } \\
\text { mydriatic pupil, } \\
\text { ophthalmoplegia, } \\
\text { reduced corneal } \\
\text { sensation, mild } \\
\text { exophthalmia }\end{array}$ & $\begin{array}{l}\text { MRI: T2 hyperintense, } \\
\text { T1 hypointense, } \\
\text { peripherally contrast } \\
\text { enhancing mass left } \\
\text { CS }\end{array}$ & $\begin{array}{l}\text { CSF: moderate } \\
\text { mixed pleocytosis. } \\
\text { Neospora, } \\
\text { cryptococcus, } \\
\text { blastomycosis- } \\
\text { negative }\end{array}$ & & $\begin{array}{l}\text { SRT x } 3 \\
\text { Fractions } \\
\text { Rx: Prednisone, } \\
\text { famotidine }\end{array}$ & $\begin{array}{l}\text { Alive at } \\
\text { time of } \\
\text { writing } \\
(1410 \\
\text { days); } \\
\text { persistent } \\
\text { mydriasis } \\
\text { OS }\end{array}$ \\
\hline 2 & $\begin{array}{l}\text { OD: Absent menace } \\
\text { response, miosis } \\
\text { OS: ophthalmoplegia, } \\
\text { mydriasis, decreased to } \\
\text { absent corneal reflex } \\
\text { OU. } \\
\text { Vertical positional } \\
\text { nystagmus, absent } \\
\text { postural reactions both } \\
\text { pelvic limbs }\end{array}$ & & & $\begin{array}{l}\text { Meningioma } \\
\text { surrounding the } \\
\text { pituitary and } \\
\text { extending to at least } \\
\text { the level of the pons. } \\
\text { Cerebellar vermis } \\
\text { herniation through } \\
\text { the foramen } \\
\text { magnum }\end{array}$ & & $\begin{array}{l}\text { Euthanasia } \\
\text { at diagnosis }\end{array}$ \\
\hline 3 & $\begin{array}{l}\text { OS: Ptosis, mydriasis, } \\
\text { elevated } 3^{\text {rd }} \text { eyelid, } \\
\text { ophthalmoparesis }\end{array}$ & $\begin{array}{l}\text { MRI: T1/ T2 } \\
\text { isointense, contrast } \\
\text { enhancing mass left } \\
\text { CS }\end{array}$ & $\begin{array}{l}\text { CSF: mild mixed } \\
\text { pleocytosis }\end{array}$ & & $\begin{array}{l}\text { Definitive RT x } \\
20 \text { fractions } \\
\text { Rx: Prednisone }\end{array}$ & $\begin{array}{l}\text { Euthanasia } \\
\text { due to } \\
\text { progression } \\
\text { of nasal } \\
\text { SCC } \\
\text { (660 days) }\end{array}$ \\
\hline 4 & $\begin{array}{l}\text { OS: Ptosis, } \\
\text { ophthalmoplegia, } \\
\text { decreased sensation on } \\
\text { the left side of the face, } \\
\text { absent corneal reflex, } \\
\text { absent palpebral reflex, } \\
\text { left head tilt, temporalis } \\
\text { and masticatory muscle } \\
\text { atrophy (L>R), reduced } \\
\text { paw replacement test in } \\
\text { both left limbs }\end{array}$ & $\begin{array}{l}\text { CT: Soft tissue } \\
\text { attenuating, } \\
\text { heterogeneously } \\
\text { contrast enhancing } \\
\text { mass affecting the left } \\
\text { maxilla, nasal cavity, } \\
\text { retrobulbar space and } \\
\text { the basisphenoid bone } \\
\text { with extension of the } \\
\text { lesion into the ventral } \\
\text { cranial vault. }\end{array}$ & & $\begin{array}{l}\text { Amelanoic } \\
\text { melanoma }\end{array}$ & $\begin{array}{l}\text { Palliative RT x } \\
4 \text { fractions, } \\
\text { melanoma } \\
\text { vaccine, } \\
\text { artificial tears } \\
\text { and neo-poly- } \\
\text { bac ophthalmic }\end{array}$ & $\begin{array}{l}\text { Euthanized } \\
\text { due to } \\
\text { progression } \\
\text { (150 days) }\end{array}$ \\
\hline 5 & $\begin{array}{l}\text { OS- absent direct and } \\
\text { consensual PLR, } \\
\text { enophthalmos, absent } \\
\text { corneal reflex, } \\
\text { ophthalmoplegia }\end{array}$ & $\begin{array}{l}\text { MRI: T1 hypointense, } \\
\text { T2/FLARE } \\
\text { hyperintense region in } \\
\text { the ventral aspect of } \\
\text { the left piriform lobe } \\
\text { with mild mass effect }\end{array}$ & $\begin{array}{l}\text { CSF: WNL } \\
\text { Brain biopsy: non- } \\
\text { diagnostic }\end{array}$ & $\begin{array}{l}\text { Poorly defined } 7 X 3 \\
\text { cm mildly firm, } \\
\text { multi-lobular mass } \\
\text { on the floor of the } \\
\text { cranial vault. It is } \\
\text { adhered to the left } \\
\text { temporal lobe but } \\
\text { does not extend into } \\
\text { the cerebral } \\
\text { parenchyma. } \\
\text { Pituitary } \\
\text { chromophobe } \\
\text { adenocarcinoma }\end{array}$ & $\begin{array}{l}\text { RT x } 18 \\
\text { fractions } \\
\text { Rx neo-poly- } \\
\text { bac ophthalmic }\end{array}$ & $\begin{array}{l}\text { Euthanasia } \\
\text { due to } \\
\text { progressive } \\
\text { seizures } \\
\text { and } \\
\text { anorexia } \\
\text { ( } 2280 \text { days) }\end{array}$ \\
\hline 6 & $\begin{array}{l}\text { OS- fixed and dilated } \\
\text { pupil, ophthalmoplegia, } \\
\text { absent corneal reflex, } \\
\text { absent direct and } \\
\text { consensual PLR. } \\
\text { Delayed paw } \\
\text { replacement test left } \\
\text { pelvic limb, facial nerve } \\
\text { paralysis, elevated } 3^{\text {rd }} \\
\text { eyelid }\end{array}$ & $\begin{array}{l}\text { MRI: T2/T1 } \\
\text { isointense, } \\
\text { peripherally contrast } \\
\text { enhancing mass left } \\
\text { CS }\end{array}$ & CSF: WNL & & Prednisone & $\begin{array}{l}\text { Euthanized } \\
\text { (630 days) }\end{array}$ \\
\hline 7 & $\begin{array}{l}\text { OS- Absent menace } \\
\text { OD- mydriasis, } \\
\text { ophthalmoparesis, } \\
\text { sluggish PLR (direct and } \\
\text { consensual), ptosis, } \\
\text { cervical pain }\end{array}$ & $\begin{array}{l}\text { MRI: Multiple T2 and } \\
\text { FLAIR hyperintense, } \\
\text { contrast enhancing } \\
\text { lesions throughout the } \\
\text { brain parenchyma. }\end{array}$ & $\begin{array}{l}\text { CSF: mild } \\
\text { mononuclear } \\
\text { pleocytosis. } \\
\text { Neospora IFA titer- } \\
1: 100 \\
\text { toxoplasma- } \\
\text { IgM } 1: 256 \\
\text { IgG negative }\end{array}$ & & $\begin{array}{l}\text { Rx: Prednisone, } \\
\text { clindamycin }\end{array}$ & $\begin{array}{l}\text { Euthanized } \\
\text { (7 days) }\end{array}$ \\
\hline
\end{tabular}


Table 1. Clinical signs, diagnostic results, and outcome in dogs and cats (Cont.).

\begin{tabular}{|c|c|c|c|c|c|c|}
\hline Patient & Neurologic deficits & Advanced imaging & $\begin{array}{l}\text { Ancillary } \\
\text { diagnostics }\end{array}$ & $\begin{array}{l}\text { Post-mortem/ } \\
\text { histopathology }\end{array}$ & Treatment & Outcome \\
\hline 8 & $\begin{array}{l}\text { OS: Absent direct and } \\
\text { consensual PLR, } \\
\text { enophthalmos } \\
\text { Intermittent right head } \\
\text { tilt } \\
\text { Seizures }\end{array}$ & $\begin{array}{l}\text { MRI: Mixed T2 } \\
\text { hyper/isointense, T1 } \\
\text { hypo/isointense } \\
\text { contrast enhancing } \\
\text { broad based lesion } \\
\text { ventral to the caudal } \\
\text { frontal lobe and } \\
\text { thalamus. Dorsal to } \\
\text { but surrounds the stalk } \\
\text { of the pituitary and } \\
\text { extends along the left } \\
\text { ventral skull to form a } \\
\text { prominent lateral dural } \\
\text { tail. }\end{array}$ & CSF: WNL & & $\begin{array}{l}\text { Phenobarbital, } \\
\text { prednisone }\end{array}$ & $\begin{array}{l}\text { Died at } \\
\text { home }(90 \\
\text { days })\end{array}$ \\
\hline 9 & $\begin{array}{l}\text { OD: Mydriasis, absent } \\
\text { PLR (direct and } \\
\text { consensual), mild ptosis, } \\
\text { ophthalmoparesis }\end{array}$ & $\begin{array}{l}\text { MRI: T2/ FLAIR } \\
\text { hyperintense, contrast } \\
\text { enhancing broad-based } \\
\text { and well demarcated } \\
\text { extra-axial mass right } \\
\text { CS }\end{array}$ & CSF: WNL & & & $\begin{array}{l}\text { Euthanized } \\
\text { (90 days) }\end{array}$ \\
\hline 10 & $\begin{array}{l}\text { Non-ambulatory } \\
\text { tetraparesis, obtunded } \\
\text { mentation } \\
\text { OD: absent menace } \\
\text { response, absent PLR, } \\
\text { ophthalomoparesis, } \\
\text { ventral strabismus. } \\
\text { Decreased facial } \\
\text { sensation right, facial } \\
\text { paresis right, absent paw } \\
\text { replacement test all } \\
\text { limbs }\end{array}$ & $\begin{array}{l}\text { MRI: An intra-axial } \\
\text { T2/FLAIR } \\
\text { hyperintense, T1 } \\
\text { iso/hypointense mass } \\
\text { in left thalamus } \\
\text { extending caudally to } \\
\text { just proximal to the } \\
\text { pons. }\end{array}$ & $\begin{array}{l}\text { CSF: marked mixed } \\
\text { pleocytosis; culture- } \\
\text { negative. } \\
\text { Crytpococcal } \\
\text { antigen- negative, } \\
\text { neosporum caninum } \\
\text { IFA titer <1:50, } \\
\text { Blastomycoses } \\
\text { antigen- negative }\end{array}$ & $\begin{array}{l}\text { Firm mass ventral } \\
\text { surface of the brain } \\
\text { obscuring detail of the } \\
\text { pons and midbrain. } \\
\text { Meningioma with } \\
\text { diffuse metastasis } \\
\text { throughout } \\
\text { leptomeninges }\end{array}$ & & $\begin{array}{l}\text { Euthanasia } \\
\text { at diagnosis }\end{array}$ \\
\hline 11 & $\begin{array}{l}\text { OD: } \\
\text { Ophthalmoplegia/paresis } \\
\text {, mydriasis, ptosis, } \\
\text { absent PLR (direct and } \\
\text { consensual) }\end{array}$ & $\begin{array}{l}\text { MRI: T2/ FLAIR } \\
\text { hyperintense, strongly } \\
\text { contrast enhancing } \\
\text { well circumscribed } \\
\text { extradural mass right } \\
\text { CS }\end{array}$ & $\begin{array}{l}\text { CSF: } \\
\text { albuminocytologic } \\
\text { dissociation } \\
\text { Blastomyces } \\
\text { antigen- negative }\end{array}$ & & & $\begin{array}{l}\text { No follow } \\
\text { up }\end{array}$ \\
\hline 12 & $\begin{array}{l}\text { OU: Reduced to absent } \\
\text { PLR, absent corneal } \\
\text { reflex, absent palpebral } \\
\text { reflex OU, poor menace } \\
\text { response OU, mydriasis } \\
\text { OU } \\
\text { OD: ophthalmoplegia } \\
\text { OS: ophthalmoparesis }\end{array}$ & $\begin{array}{l}\text { MRI: Meningeal } \\
\text { enhancement with } \\
\text { mild extension into the } \\
\text { sulci of the right and } \\
\text { left parietal lobes. } \\
\text { Normal CS }\end{array}$ & CSF: WNL & & & $\begin{array}{l}\text { Markedly } \\
\text { improved } \\
\text { ( } 240 \text { days) } \\
\text { No } \\
\text { additional } \\
\text { follow up }\end{array}$ \\
\hline 13 & $\begin{array}{l}\text { OD: } \\
\text { Ophthalmoplegia/paresis } \\
\text {, reduced palpebral } \\
\text { reflex }\end{array}$ & $\begin{array}{l}\text { MRI: strongly contrast } \\
\text { enhancing mass within } \\
\text { the right CS, dural tail } \\
\text { observed. The mass } \\
\text { extends through the } \\
\text { orbital fissure into the } \\
\text { right retrobulbar space }\end{array}$ & $\begin{array}{l}\text { CSF: Mild } \\
\text { mononuclear } \\
\text { pleocytosis }\end{array}$ & & $\begin{array}{l}\text { Prednisone } \\
(1 \mathrm{mg} / \mathrm{kg} / \text { day })\end{array}$ & $\begin{array}{l}\text { Euthanized } \\
\text { due to } \\
\text { seizures } \\
\text { and weight } \\
\text { loss (1260 } \\
\text { days) }\end{array}$ \\
\hline 14 (cat) & $\begin{array}{l}\text { OS: Absent menace } \\
\text { response and palpebral } \\
\text { reflex, reduced PLR, } \\
\text { ophthalmoparesis/plegia, } \\
\text { corneal sensation absent, } \\
\text { mydriasis } \\
\text { Left sided head tilt }\end{array}$ & & & $\begin{array}{l}\text { Infiltrative mass } \\
\text { obliterating the left CS } \\
\text { Adenosquamous } \\
\text { carcinoma }\end{array}$ & & $\begin{array}{l}\text { Euthanasia } \\
\text { due to } \\
\text { progression } \\
\text { (14 days) }\end{array}$ \\
\hline 15 (cat) & $\begin{array}{l}\text { OS: Mydriasis, } \\
\text { ophthalmoplegia, absent } \\
\text { PLR (direct and } \\
\text { consensual) }\end{array}$ & & $\begin{array}{l}\text { CSF: } \\
\text { albuminocytologic } \\
\text { dissociation }\end{array}$ & $\begin{array}{l}\text { Mass lesion in the } \\
\text { region of the left CS } \\
\text { High grade malignant } \\
\text { lymphoma }\end{array}$ & & $\begin{array}{l}\text { Euthanized } \\
\text { (14 days) }\end{array}$ \\
\hline
\end{tabular}

Abbreviations: (CS): cavernous sinus; (PLR): pupillary light reflex; (OS): left eye; (OD): right eye; (OU): both eyes; (WNL): within normal limits;

$(\mathrm{SRT})$ : stereotactic radiation therapy; $(\mathrm{RT})$ : radiation therapy; $(\mathrm{Rx})$ : prescribed. 


\section{Discussion}

To our knowledge there have been two previous retrospective studies and a limited number of case reports of CSS in dogs and cats to date (Lewis et al., 1984; Theisen et al., 1996; Tidwell et al., 1997; Fransson et al., 2000; Rossmeisl et al., 2005; Hernandez-Guerra, 2007; Perazzi et al., 2013; Guevar et al., 2014). The clinical prevalence of CSS has been previously considered rare. In our institution, we identified 23 suspected cases in 13 years, which suggests that perhaps CSS is more common and perhaps underdiagnosed in practice. Similarly, the recent case report in a Holstein bull with confirmed CSS secondary to bacterial abscessation poses the question as to the frequency in large animals.

Findings of anisocoria in any patient should prompt a full ophthalmic and neurologic assessment. Assessment of internal and/or external ophthalmoplegia or ophthalmoparesis is critical to obtaining a diagnosis of cavernous sinus syndrome. The contralateral eye should be used as a control (when unilateral) for the affected eye and its movements in the dorsal, ventral, lateral, and medial directions should be carefully assessed.

Internal ophthalmoparesis or paralysis is the result of lack of innervation to the iris and ciliary muscles and can be assessed with the pupillary light reflex and presence of mydriasis. In the present study, the 3 most common neurologic deficits were external ophthalmoparesis or paralysis (13/15), internal ophthalmoparesis or paralysis (11/15), and mydriasis (10/15).

In addition to typical signs of CSS, 3 patients in the present study had an intermittent or persistent head tilt at the time of diagnosis. One additional patient had temporalis and masticatory muscle atrophy. These patients had disease extending past the boundaries of the cavernous sinus involving the inner ear or brainstem that can explain these concurrent neurologic deficits. Neoplasia was identified as the most common underlying etiology of CSS in this study, which is consistent with the findings of previous studies (Theisen et al., 1996; Rossmeisl et al., 2005). In the present study, meningioma was the most common mass lesion (2/6) identified within the cavernous sinus. The remaining 4 patients with histopathological evaluation each had different neoplastic lesions.

In one previous study a mass lesion was identified in 2 dogs (neuroendocrine carcinoma, meningioma) and 2 cats (lymphoma, metastatic adenocarcinoma), and 4 cats were diagnosed with infectious diseases (Cryptococcus neoformans ( $\mathrm{N}=2$ ), Toxoplasma gondii, and feline infectious peritonitis) (Theisen et al., 1996). In another study histopathological diagnoses in $5 / 6$ dogs showed one of each of the following tumor types: chemodectoma, meningioma, lymphoma, metastatic thyroid carcinoma, and primitive neuroectodermal tumor (Rossmeisl et al., 2005). Chondrosarcoma within the cavernous sinus has been reported in a Rottweiler, that dog was treated with anti-inflammatory doses of steroids and euthanized 1 year later due to progression of disease. Lewis et al. (1984) previously reported ophthalmoplegia as a result of metastatic adenocarcinoma confirmed on post-mortem examination.

Rarely, non-neoplastic and non-infectious causes of CSS are reported. A feline leukemia positive Korat cat had necropsy confirmed multiple cartilaginous exostosis resulting in CSS, among other lesion in the appendicular and axial skeleton (Perazzi et al., 2013). This cat had facial hypoalgesia on the same side of the CS lesion. Debate exists as to if the maxillary branch of the trigeminal nerve should be included in the cranial nerves affected by lesions in the CS.

Our study included 2 dogs with reduced facial sensation consistent with a lesion in the maxillary branch of the trigeminal nerve. It appears clinically that if the mass lesion expands within the CS both branches of the trigeminal nerve can be affected. Cranial nerves III, IV, VI, and the ophthalmic branch of $\mathrm{V}$ exit the oval foramen together while the maxillary branch of $\mathrm{V}$ exits the round foramen. Both foramina are contained within the limits of the CS (orbital fissure to petro-occipital canal).

The lack of infectious etiologies in the present study may be a result of a small feline sample size or geographic location variability. A recent study described isolated cases of oculomotor neuropathy of presumed idiopathic origin (Tetas Pont et al., 2017). If the MRI findings and neuro-ophthalmic examination are supportive of oculomotor nerve dysfunction in the absence of other deficits, this could be considered a differential diagnosis.

Our overall survival times in dogs are higher compared to previous studies. A previous retrospective study of bilateral CSS in dogs reported follow up on 4 patients that received chemotherapeutic treatment with a median survival time of 199 days (range 16-392 days) (Rossmeisl et al., 2005). Another retrospective study including 4 dogs and 8 cats reported follow up on 2 dogs and 1 cat, with longest survival time of 18 months (540 days) (Theisen et al., 1996). The longest reported survival time with metastatic thyroid adenocarcinoma resulting in bilateral CS invasion was 150 days, in a dog that was not treated.

In the present study, we followed 13 patients over 47 months or until euthanasia, and the median survival times were 1035 days with radiation therapy, 360 days with anti-inflammatory steroid therapy, and 14 days without any therapy. Longer survival times in treated dogs in our study are likely due to the use of radiation therapy. Another potential reason for variability in 
outcome is early detection via thorough neuroophthalmic examination, magnetic resonance imaging, or computed tomography.

In the present study, cases were presented or referred with equal frequency to the ophthalmology and neurology services, so all clinicians should be aware of the syndrome and its common clinical presentation. Clinicians in both specialties should always perform a complete neuro-ophthalmic examination, including ocular motility assessment and corneal sensation in cases of anisocoria, and consider CSS as a potential cause.

In conclusion, cavernous sinus syndrome in dogs and cats is often the result of a neoplastic process within the cavernous sinus, however, no one neoplastic process appears overrepresented. Cavernous sinus syndrome may be more common than previously reported. By being aware of the syndrome and performing a thorough ophthalmic and neurologic examination in any patient with mydriasis, cases may be identified sooner in the progression of disease and the prognosis may improve.

\section{Conflict of interest}

The authors declare that there is no conflict of interests.

\section{References}

Dewey, C.W. 2008. Practical Guide to Canine and Feline Neurology. $2^{\text {nd }}$ edition. Iowa: WileyBlackwell.

Ebert, S., Pilgram, S., Bahr, M. and Kermer, P. 2009. Bilateral ophthalmoplegia due to symmetric cavernous sinus metastasis from gastric adenocarcinoma. J. Neurol. Sci. 279, 106-108.

Evans, H.E. and de Lahunta, A. 1988. Miller's Guide to the Dissection of the Dog. Philadelphia: W.B. Saunders Company.

Fernandez, S., Godino, O., Martinez-Yelamos, S., Mesa, E., Arruga, J., Ramón, J.M., Acebes, J.J. and Rubio, F. 2007. Cavernous sinus syndrome A series of 126 patients. Medicine 86, 278-281.

Fransson, B., Kippenes, H., Silver, G.E., Silver, G.E. and Gavin, P.R. 2000. Magnetic resonance diagnosis: cavernous sinus syndrome in a dog. Vet. Radiol. Ultrasound 41, 536-538.
Guevar, J., Gutierrez-Quintana, R., Peplinski, G., Helm, J.R. and Penderis, J. 2014. Cavernous sinus syndrome secondary to intracranial lymphoma in a cat. J. Feline Med. Surg. 16, 513-516.

Hernandez-Guerra, A.M., Lopez-Murcia, M.M., Planells, A., Corpa, J.M. and Liste, F. 2007. Computed tomographic diagnosis of unilateral cavernous sinus syndrome caused by a chondrosarcoma in a dog: a case report. Vet. J. 174, 206-208.

Jacob, S., Drees, R., Pinkerton, M., Bentley, E.M. and Peek, S.F. 2015. Cavernous Sinus syndrome in a Holstein bull. Vet. Ophthalmol. 18(2), 164-167.

Lewis, G.R., Blanchard, G.L. and Trapp, A.L. 1984. Ophthalmoplegia caused by thyroid adenocarcinoma invasion of the cavernous sinuses in the dog. J. Am. Anim. Hosp. Assoc. 20, 805-812.

Penderis, J. 2004. Disorders of the eyes and vision. In: Platt, S.R. and Olby, N.J. eds. BSAVA manual of canine and feline neurology. $3^{\text {rd }}$ edition. Gloucester: BSAVA, pp: 133-154.

Perazzi, A., Bernardini, M., Mandara, M., De Benedictis, G.M., De Strobel, F. and Zotti, A. 2013. Cavernous sinus syndrome due to osteochondromatosis in a cat. J. Feline Med. Surg. 15(12), 1132-1136.

Rossmeis1, J.H., Higgins, M.A., Inzana, K.D., Herring, I.P. and Grant, D.C. 2005. Bilateral cavernous sinus syndrome in dogs: 6 cases (1000- 2004). J. Am. Vet. Med. Assoc. 226, 1105-1111.

Tetas Pont, R., Freeman, C., Dennis, R., Hartley, C. and Beltran, E. 2017. Clinical and magnetic resonance imaging features of idiopathic oculomotor neuropathy in 14 dogs. Vet. Radiol. Ultrasound 58(3), 334-343.

Theisen, S.K., Podell, M., Schneider, T., Wilkie, D.A. and Fenner, W.R. 1996. A Retrospective study of cavernous sinus syndrome in 4 dogs and 8 cats. J. Vet. Intern. Med. 10, 65-71.

Tidwell, A.S., Ross, L.A. and Kleine, L.J. 1997. Computed tomography and magnetic resonance imaging of cavernous sinus enlargement in a dog with unilateral exophthalmos. Vet. Radiol. Ultrasound 38, 363-370. 